\title{
Light and electron microscopic structure of goat's retina
}

\author{
S. M. Soliman ${ }^{\text {1* }}$ Z. A. A. Adam ${ }^{2}$, U. K. M. Abd allah ${ }^{1}$ \\ ${ }^{1}$ Department of Cytology and Histology and ${ }^{2}$ Department of Anatomy and Embryology, Faculty of \\ Veterinary Medicine, Beni-Suef University
}

\begin{abstract}
The present study was conducting aiming to throw the light on the retinal structure on the level of both light and electron microscope. Eyeballs of 35 adult clinically healthy goats of both sexes were collected from Beni- Suef abattoir. The eyeballs were clinically examined before they were dissected and fixed in $10 \%$ buffed neutral formalin and in Bouin's solution for 24 hours. The specimens were then processed for light and transmission electron microscope. The retina (pars optica retinae) of the goats extends rostrally to cover the ciliary body as pars ciliaris retinae and the iris as the pars iridis retinae. Pars optica retinae and pars iridis retinae form the light non sensitive parts of the retina, while the sensitive part except at the transition zone; the ora serrata and the optic disc, appeared to be formed of ten layers, named from outward to inward as, retinal pigmented epithelium, rods and cones layer (photoreceptor cell layer), external limiting membrane, outer nuclear layer (cell bodies and nuclei of the photoreceptor cells), outer plexiform layer, inner nuclear layer (contained the horizontal, bipolar, Muller and amacrine cells), inner plexiform layer, ganglionic cell layer, nerve fiber cell layer (unmyelinated nerve fibers) and internal limiting membrane.
\end{abstract}

The retina which the neural layer of the eyeball (Tunica nervosa bulbi) is the whitish membrane forming the innermost portion of the goat's eyeball. It is represented by two parts; a sensory photosensitive portion and a non sensory one. The latter extend rostrally to cover the ciliary body and the iris. The point of transition from the photosensitive portion to the non photosensitive portion is called ora ciliaris retinae in domestic animals and ora serrata in human (Banks, 1993). In the available literature, it has been found that the structure of the eyeball studied in many species of animals including some laboratory animals as Geunia pigs (Spira Milman, 1979), rats (Smell et al., 1987), ferrets (Braekevelt, 1982), mouse (Carter-Dawson and lavil, 1979) and rabbits (Mills and Massey, 1992); pet animal as dogs (Miyake et al., 2004) and cats (Braekevelt, 1990) and domestic animals as horse (Altuny, 2000), camels (Derbalah, 2001), cattle (Altuny, 2004), buffaloes (Kassab and Sugita, 2001), sheep (Nilsson et al., $1973 \mathrm{a}, \mathrm{b}$ ). The goats received a little attention of the researchers. Furthermore, none of above mentioned articles have dealt with the structure of the retina at the level of either light or transmission electron microscope. Therefore, the present investigation was conducted aiming to full fill this gap and to establish normal standard against which any

\footnotetext{
* Corresponding author. Tel.: +20 016 7102575; Fax: +20 0822327982

E-mail address: soliman@bsu.edu.eg

(Shehata M. Soliman)
}

pathological conditions involving the eyeball could be easily diagnosed and managed.

\section{Materials and methods}

Eyeballs of 35 adult clinically healthy goats of both sexes were collected from Beni-Suef abattoir. The eyeball were bisected and fixed in $10 \%$ buffered neutral formalin and in Bouin's solution for 24 hours. The specimens were then dehydrated in ascending grades of ethanol, cleared in two changes of xylene, impregnated in soft paraffin and finally embedded in paraffin wax. 4-6 $\mu \mathrm{m}$ thick sections were cut and stained Haematoxyline and Eosin (H\&E), Gomori's reticulin method, Toluidine blue stain, Standard Sudan black B method and Bielschowsky's silver stain. The all mentioned stains used for demonstration the light microsopic structure of the retina and applied as outlined by Bancroft and Stevens (1996).

The eyeballs of ten clinically healthy goats, extirpated just after slaughter where $1-3 \mathrm{~mm}$ thick pieces were excised from the retina and prefixed in $4 \%$ gluteraldhyde in phosphate buffer solution ( $\mathrm{pH}$ 7.4) at room temperature for 4 hours then processed for examination by transmission electron microscope. Semi thin sections $0.5-1 \mu \mathrm{m}$ were cut by a glass knife, and stained by Toluidine blue then examined by the optical light microscope for determination of the selected areas (Richardson et al., 1960). Ultra thin sections, $50-60 \mathrm{~nm}$ thick, of the selected area were cut, mounted on copper grids and were 
contrasted with uranyl acetate ethanol followed by lead citrate stain (Reynolds, 1963). The sections were examined using JEOL JEM 100CX II transmission electron microscope in the electron microscope unit, Assiut University.

\section{Results}

The retina (pars optica retinae) of the eye goats is the innermost portion of the eyeball which was sensitive to light and colors. It extended rostrally to cover the ciliary body as pars ciliaris retinae and the iris as the pars iridis retinae. Both formed the light non sensitive parts of the retina.

Light sensitive part. Except at the transition zone; the ora serrata and the optic disc, the goat's retina appeared to be formed of ten layers, named from outward to inward as, retinal pigmented epithelium, layer of rods and cones (photoreceptor cell layer), external limiting membrane, outer nuclear layer, outer plexiform layer, inner nuclear layer, inner plexiform layer, ganglionic cell layer, nerve fiber cell layer and internal limiting membrane (Fig.1).

The retinal pigmented epithelium. The retinal pigmented epithelium consisted of a single row of cuboidal cells resting on a clear basal lamina, it contained central, spherical and vesicular (euchromatic) nuclei. The nuclei contained well demarcated prominent nucleoli. Numerous dark brown melanin granules (melanosomes) of variable shapes and sizes are aggregated in the apical part of the cells (Fig. 2 and 3).

The cytoplasm of these cells contained also scarce amount of rER and numerous sER, secretory vesicles, secondary lysosomes as well as electron dense irregular masses resembling the rod's outer segment. Zonula adherent and tight junctions were seen between the adjacent epithelial cells. Finger - like projections were, also, noticed at vitreal end to interdigitate and to house the rod outer segments. it did not contain any melanin granules.

The basal parts were characterized by the presence of numerous deep basal infoldings. They were rested on a complex basement membrane (Bruch's membrane) which separated the choroid from the retina.

The photoreceptor layer. Two types of photoreceptors could be differentiated in this layer; the rods and the cones. They were considered modified neurons; composed of an outer (photosensitive part) and an inner segment (Fig. 4). The rod outer segment was elongated uniform structures which were longer and more numerous than those of the cone. Its free end lodged in the apical processes of the pigmented epithelium (Fig. 5).

The cone outer segments appear conical in shape with tapered free ends and wide bases. They were shorter than the rod outer segments and did not reach the pigmented epithelium (Fig. $4)$.

Each cone outer segment was consisted of several parallel double membranous discs (stalks) separated from each other by narrow regular spaces and the discs were separated from the covering plasma membrane (Fig. 6). The discs were closely packed and have narrower spaces than the corresponding rod outer segment discs.

The inner segment of both the rods and the cones were composed of two parts; an outer ellipsoid and an inner myoid. The myoid of the rod appeared as electron dense irregular structure containing rough and smooth endoplasmic reticulum (Fig. 7). The ellipsoid of both contained many vesicles and numerous tubular mitochondria with long filamentous cristae (Fig. 8). The mitochondria in cone ellipsoid were more numerous than that of rods.

The external limiting membrane. The external limiting membrane appeared as a dark line separating the rods and cones layer from the outer nuclear layer. It contained argyrophilic material (Fig. 9). By electron microscopy, the external limiting membrane was untrue membrane. It could be seen as an electron dense line representing the close adherence of the zonulae adherences between Müller cells and between them and the inner segments of photoreceptor cells.

The outer nuclear layer. As shown in (Fig. 10), the outer nuclear layer was formed mainly of cell bodies and nuclei of the photoreceptor cells arranged in 6-7 rows. The most superficial row constituted the lightly stained cone nuclei and the reminders were mostly formed of the darkly stained rod nuclei. The cone nuclei appeared large, oval to spherical, with peripherally distributed euchromatin and more electron lucent nucleoplasm (Fig. 11). On the other hand, the rod nuclei were smaller in size, oval to spherical in shape with more centrally - distributed heterochromatin and more electron dense nucleoplasm. Connecting fibers and axons of rod and cone cells as well as Müller processes were, also, noticed in the outer nuclear layer.

The outer plexiform layer. Is that layer separating the outer and inner nuclear layers. It could be seen as the axons of the rods and cones 
which synapsed with the dendrites of inner nuclear layer. The cone axons appeared to be ended as large, irregular synaptic pedicles, cone pedicles, which synapsed with the cells of the inner nuclear layer (Fig. 12).

The terminal end of the rod axon was observed as a flask-shaped structure, the rod spherule, that synapsed with the cells in the inner nuclear layer. Such synaptic sites contained many synaptic vesicles and numerous large rounded to oval mitochondria with their long tubular cristae. The area of the outer plexiform layer was supplied by a special double-walled blood capillaries lined by two types of cells; endothelial cells and an elongated, flattened, electron dense cells enclosed within the basement membrane.

The inner nuclear layer. It was intervening between outer and inner plexiform layers. It was thinner than the outer nuclear layer, contained cells of different shapes and sizes and were arranged in 3-4 rows. The cellular components of this layer were the horizontal, bipolar, Müller and amacrine cells.

The horizontal cells were large, oval cells contained spherical to oval euchromatic nuclei with prominent nucleoli (Fig. 13).

The bipolar cells, as shown in Figure (14), were numerous neurons and appeared in two forms euchromatic and heterochromatic cells. The cells were randomly distributed within the inner nuclear layer.

The Müller cells were elongated astrocytes. At the outer end, the cells were fused with the rods and cones and at the inner end they were fused with each other. The cells fulfill the spaces between the various neural elements between the external and internal limiting membranes. They possessed a triangular or angular, more electron dense nuclei. Their plasmalemma showed extensions lodged between the cell types (Fig. $15)$.

The amacrine cells occupied the innermost portion and formed an incomplete layer at the vitreal margin of this layer. They were identified by their deeply indented nuclei. Their rounded cell bodies contours and their processes were extending to the inner plexiform layer. Their electron dense cytoplasm contained many mitochondria, rER and free ribosomes (Fig. 16).

The inner nuclear layer was supplied by double walled capillaries lined by two types of cells resembling that of the outer plexiform layer (Fig. 17).

The inner plexiform layer. The layer was located between the inner nuclear and the ganglionic cell layer. It contained the cytoplasmic processes of the bipolar and the amacrine cells that synapsed with dendritic processes of the ganglionic cell (Figs. 18).

The ganglionic cell layer. The layer was formed of a single and, occasionally, double rows of two types of cells; large spherical cells and small oval cells. The large spherical cells contained large spherical euchromatic nuclei with prominent eccentric nucleoli. The cytoplasm was abundant and contained numerous mitochondria, sER, rER and free ribosomes (Fig. 19).

The optic nerve fiber cell layer. The layer appeared to be formed of unmyelinated nerve fibers, belonging to the large ganglionic cells. They run parallel to the long axis of the retina (Fig. 20). The nerve fibers were supported by glia cells, mainly, Müller cells. At the level of the optic disc, the nerve fibers were converged and crossed the retina to form the optic nerve.

The internal limiting membrane. The internal limiting membrane was seen just close to the vitreous humour (Fig. 1). Electron microscopic examination of this membrane showed that it was an electron dense osmiophilic, thick membrane separating the Müller cells from the vitreous body (Fig. 21). Numerous rER and many mitochondria were observed inside the end feets of the Müller's cells.

Light non - sensitive part. The non sensory portion of such tunica began at the ora serrata. It extended anteriorly to cover the ciliary body as the pars ciliaris retinae and the iris as the pars iridis retinae. It was a type of stratified epithelium. The outer cell is non pigmented and the inner layer was, in contrast, heavily pigmented, these pigments masked any details of the above mentioned cells (Fig.22). 

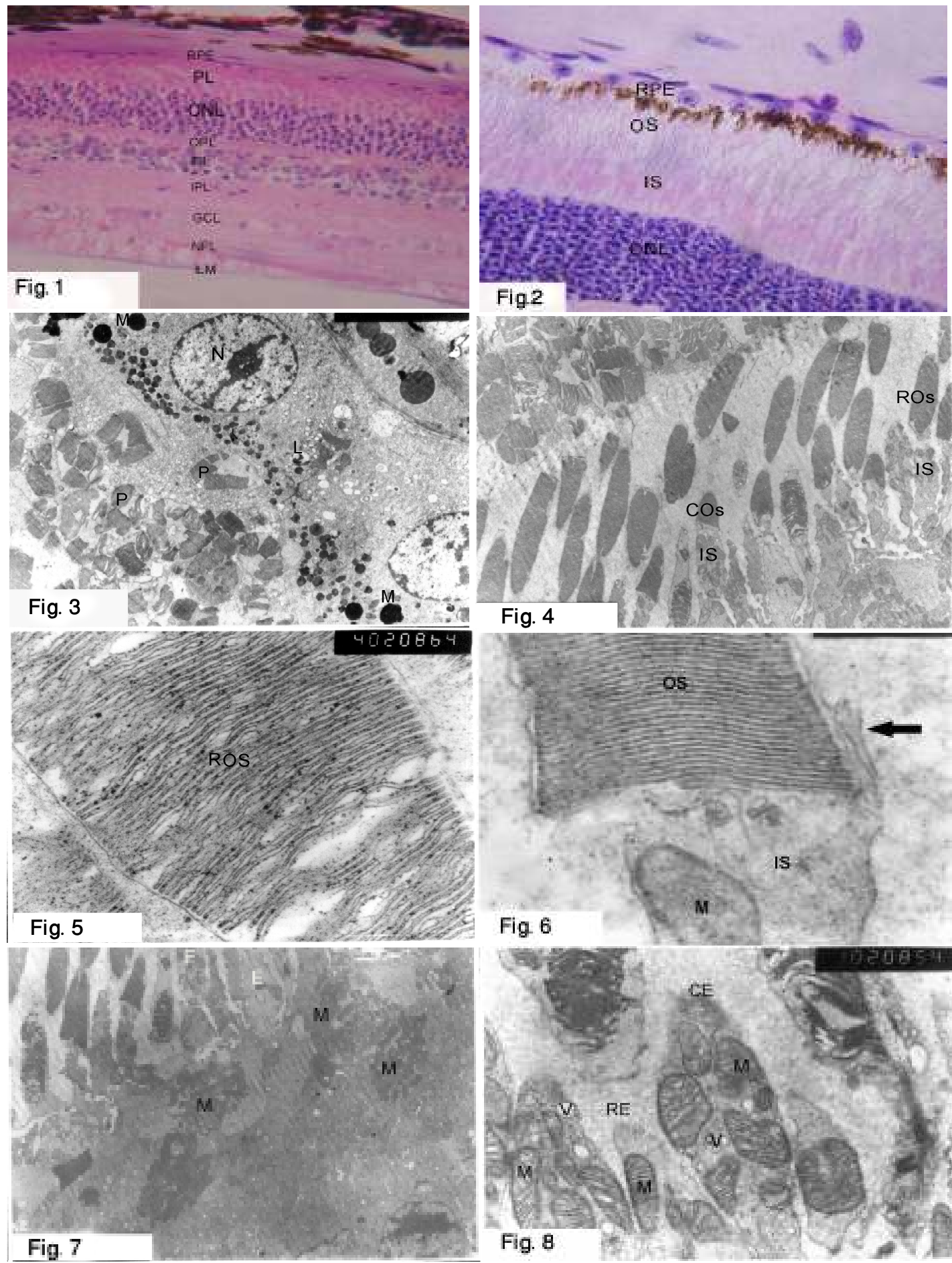

Fig. (1) : A Photomicrograph of goat's retina showing the different layers of the retinal wall; retinal pigment epithelium (RPE), photoreceptor layer (PL), outer nuclear layer (ONL), outer plexiform layer (OPL), inner nuclear layer (INL), inner plexiform layer (IPL), ganglionic cell layer (GCL), nerve fiber layer (NFL) and internal limiting membrane (ILM). H \& E, X 400 .

Fig. (2): A Photomicrograph of goat's retina showing the retinal pigment epithelium (RPE) in the non tapetal area. Note that the cells are cuboidal containing apically located melanin granules. Notice that both the outer segment (OS), and inner segment (IS) of the photoreceptor layer and the outer nuclear layer (ONL). H\&E, X1000.

Fig. (3): Transmission electron micrograph of goat's retina showing that the retinal pigment epithelium was formed of low cuboidal cells containing apically - situated melanosomes $(M)$ of different shapes and sizes, spherical nucleus $(\mathrm{N})$ and secondary lysosome (L). Notice the photoreceptor outer segment (P). Uranyl acetate and lead citrate, $X \mathbf{2 7 0 0}$.

Fig. (4): TEM of retina of goat showing that each of the cones and the rods was formed of outer and inner segments. Notice cone outer segment (COS), inner segment (IS), rod outer segment (ROS) and inner segment (IS). Uranyl acetate and lead citrate, X 2700. Fig. (5): TEM of retina of goat showing the rod outer segment (ROS). Notice that the discs were separated from the plasmalemma. Uranyl acetate and lead citrate, $\mathrm{X} 40000$.

Fig. (6): TEM of goat's retina showing the cone's outer segment (OS), inner segment (IS) and calycal process (arrow). Notice the presence of mitochondria $(M)$ in the inner segment. Uranyl acetate and lead citrate, $X 40000$.

Fig. (7): TEM of photoreceptors of goat's retina showing that the inner segment of either rods or cones was composed of two parts; outer ellipsoid (E) and inner myoid (M).Uranyl acetate and lead citrate, X2700. 

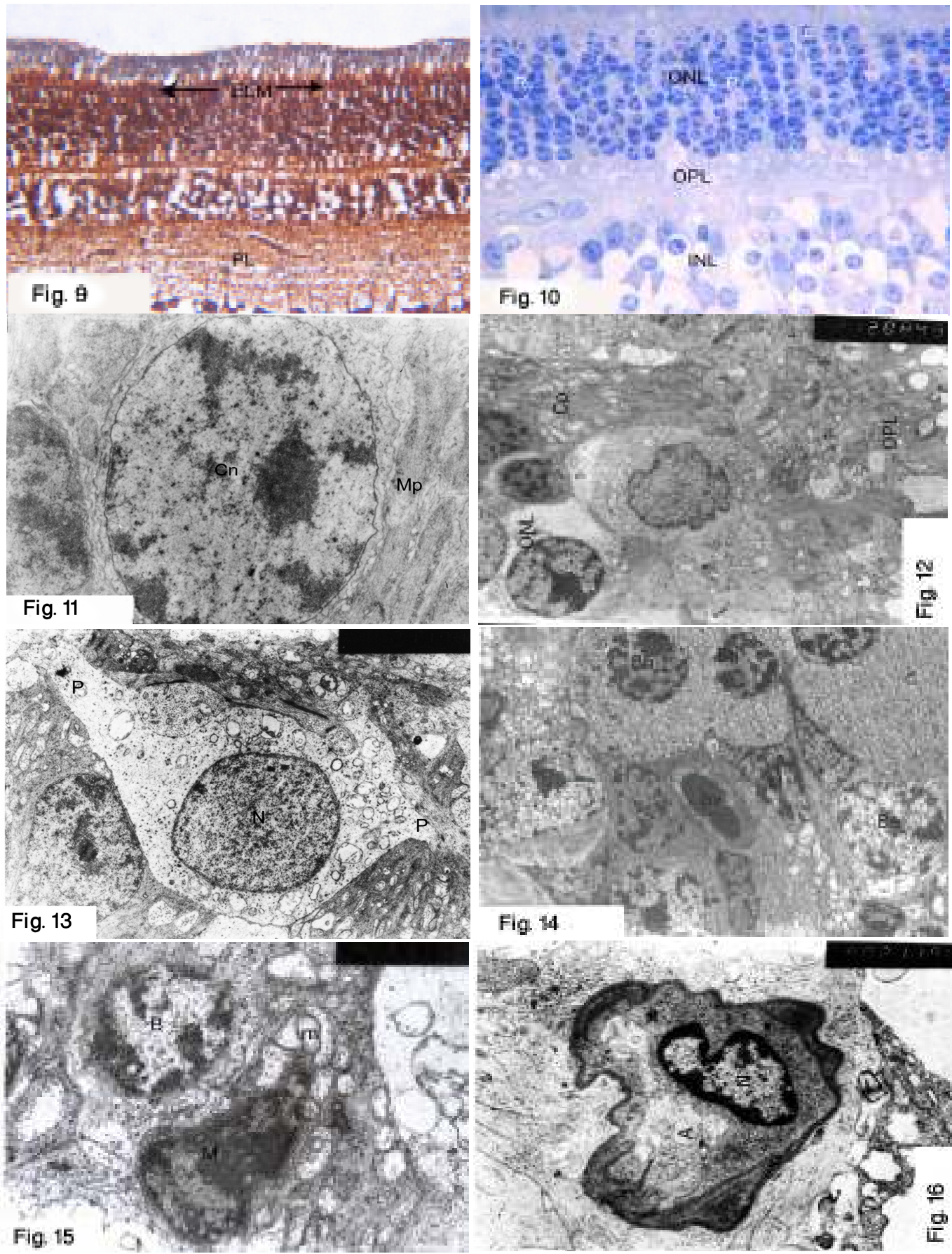

Fig. (8): TEM of both rod (RE) and cone (CE) ellipsoid showing several mitochondria (M) and vesicles (V). Uranyl acetate and lead citrate, $\mathrm{X10000}$.

Fig. (9): A micrograph of the goat's retina showing the external limiting membrane (ELM). Note fine reticular fibers in plexiform layer (PL). Gomori's reticulin method, X400.

Fig. (10): A micrograph of goat's retina showing the outer nuclear layer (ONL) which was formed of euchromatic cone nuclei (C) and heterochromatic rod nuclei (R). Note the outer plexiform layer (OPL) and inner nuclear layer (INL). Toluidine blue, X 1000.

Fig. (11): TEM of the retina of goat showing a cone cell with a large vesicular euchromatic nucleus (Cn). Note the presence of Müller cell processes $(\mathrm{Mp})$ between the photoreceptor cells. Uranyl acetate and lead citrate, $X \mathbf{8 0 0 0}$.

Fig. (12): TEM of the outer plexiform layer (OPL) showing a cone pedicle (CP) which synapsed with processes of the inner nuclear layer. Notice the cone nucleus in the outer nuclear layer (ONL). Uranyl acetate and lead citrate, $X 2700$.

Fig. (13): TEM of the inner nuclear layer of the goat's retina showing one the electron lucent horizontal cell with its oval nucleus (N). Note the horizontally oriented processes $(P)$. Uranyl acetate and lead citrate, $X 4000$.

Fig. (14): TEM of the inner nuclear layer of the goat's retina showing the two types of bipolar cells; cells with euchromatic (Be) and cells with heterochromatic nuclei $(\mathrm{Bh})$ and Müller cells $(\mathrm{M})$ inbetween. Note the presence of blood vessel (bv). Uranyl acetate and lead citrate, X2700.

Fig. (15): TEM in the inner nuclear layer of the goat's retina showing one of the Müller cells (M) lodged between the bipolar cells (B). Notice the numerous mitochondria (M) within the Müller cell cytoplasm. Uranyl acetate and lead citrate, 8000.

Fig. (16): TEM in the inner nuclear layer of the goat's retina showing one of the amacrine cells (A). It was characterized by its deep invaginated nucleus $(\mathrm{N})$. Uranyl acetate and lead citrate. $X 8000$. 


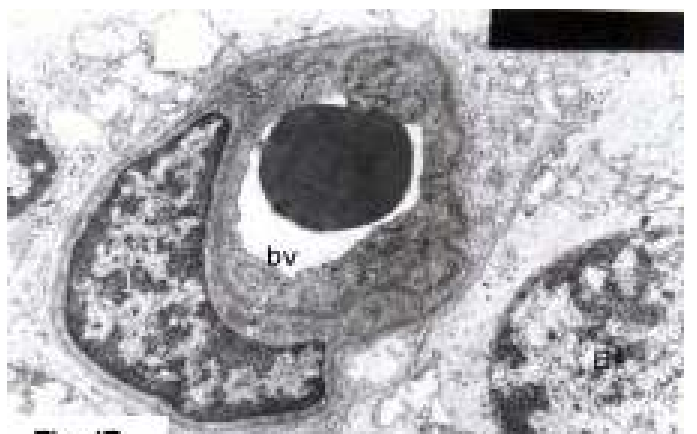

Fig. 17
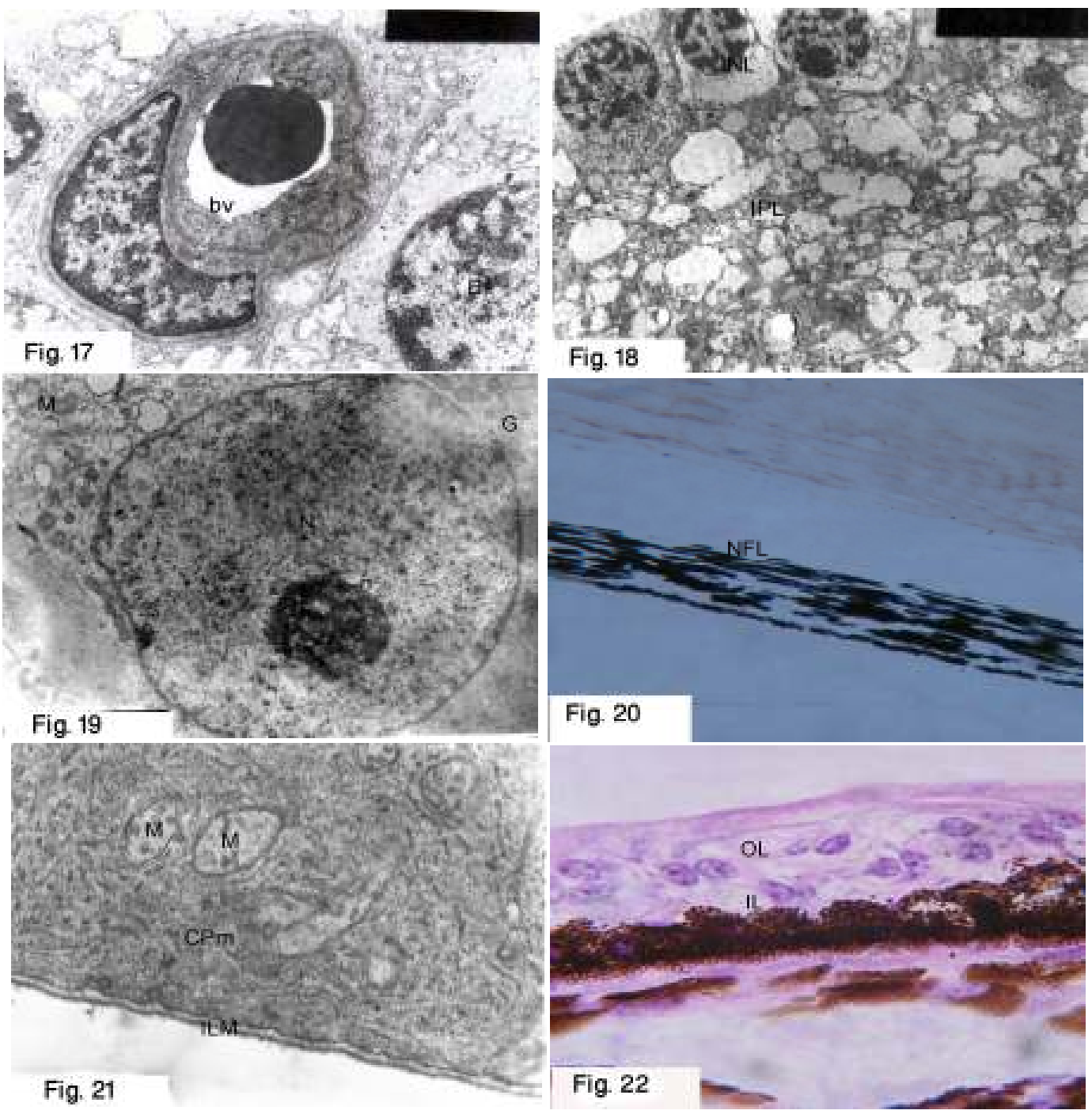

Fig. (17): TEM of the inner nuclear layer of the goat's retina showing a double walled blood vessels (bv) lined by two types of cells; normal endothelial cells(1) and electron dense flattened cells (2). One of the bipolar cells (B). Uranyl acetate and lead citrate, X6700. Fig. (18): TEM of the goat's retina showing that the inner plexiform layer (IPL) was formed of the cytoplasmic processes of the inner nuclear layer (INL). Uranyl acetate and lead citrate, X 2700.

Fig. (19): TEM of ganglionic layer of the goat's retina showing a ganglionic cell (G) with its large nucleus (N). the latter contained prominent nucleolus (n). Notice the presence of many mitochondria (M). Uranyl acetate and lead citrate, X 6700.

Fig. (20): A Photomicrograph of the goat's retina showing the black - stained nerve fibers in the nerve fiber layer (NFL). Notice that the fibers run parallel to the surface of the retina. Bielschowsky's silver stain, X400.

Fig. (21): TEM in the goat's retina showing the inner limiting membrane (ILM). Note the end feet of the Müller cells (CPm) which contained many mitochondria (M). Uranyl acetate and lead citrate, $X 2000$.

Fig. (22): A higher magnification of pars ciliaris retinae showing the outer non pigmented epithelium (OL) and the inner heavily pigmented one (IL). H \& E, X 1000.

\section{Discussion}

Due to the great importance of the retina in vision sensation and allowing the individual to react with the surrounding environment, the retina has been widely studied in a variety of species (Kuwabara, 1979; Altuny, 1997; 2000, 2004; Samuelson, 2007).

The goat's retina appeared to be composed of a sensory part and a non sensory part. The former represented the neuroepithelial tunica that was sensitive to light while the non sensory portion extended anteriorly to cover the ciliary body as pars ciliaris retinae and the iris as pars iridis retinae. The above mentioned findings were augmented by the findings of Samuelson, (1999); Hees and Sinowatz, (2000). The latter authors added that the image formation is the primary function of the retina.

The pars optica retinae of goats resembled that of other mammals as it composed of ten layers named from outside to inside as the retinal pigment epithelium, the visual cell layer, the outer limiting membrane, the outer nuclear layer, the outer plexiform layer, the inner nuclear layer, the inner plexiform layer, the gnglionic cell 
layer, the optic nerve fiber layer and the inner limiting membrane. The same findings detected in many species as bovine (Aly, 2003), camels (Derballah, 2001), canine (Shively et al., 1970) and equine (Ehrenhofer et al., 2002). On the other hand, Mohammed, (2004) reported that the ostrich's retina was composed of nine layers only as he not considered the outer limiting membrane as a true layer.

As reported in many vertebrates (Nilsson, 1978; Altuny, 2007), the present investigation revealed that the retinal pigment epithelium was the outermost layer of the retina and was composed of a single row of cuboidal cells. These cells were provided with numerous basal infoldings. In the opinion of most histologists (Boulton and Day haw-Baker, 2001; Altuny, 2004) the basal infoldings had a great role in the material transport from choriocapillaries to the photoreceptors. The presence of many apical processes which interdigitated with the photoreceptor outer segments were also met in other mammalian species. These processes were necessary for Phagocytosis of outer segment discs (Bok, 1985), for stabilization of photoreceptor outer segments (Enoch, 1979), and for adhesion of the neurosensory retina (Braekevelt, 1988). Unlike the findings of Braekevelt, (1988); Boulton and Dayhaw-Baker, (2001) who described two types of processes projecting from the pigment cells, only one type projections have been recorded in goat's retina. Our finding was met with that of the camel's eye (Altuny, 2007). The processes were finger-like and extended between the rods and cones processes.

The pigmented epithelial cells of goat's retina were found to be connected with each other by tight junctions and zonula adherents as it was mentioned in many other mammalian species (Boulton, 1991; Altuny, 2007). The authors agreed that the lateral junction played a role for the formation of a selective barrier for metabolites and ion transport.

The electron microscopic examination of the goat's retinal pigment epithelium revealed euchromatic nuclei, abundant mitochondria, smooth endoplasmic reticulum and few rough endoplasmic reticulum. These findings agreed with the results of (Altuny, 1997, 2007), and reflected a high metabolic activity of these cells.

The second layer of the goat's retina was the photosensitive layer which appeared as numerous elongated cylindrical segments. The traditional separation of retinal photoreceptors into rods or cones was originally proposed by Schultze, (1866) depending on the morphological characters of the cells. Polyak, (1957); Duke-Elder, (1958); Aly, (2003) decided that the rods of the photoreceptor cell layer have cylinderical inner and outer segments, while the cone of the same layer have a shorter conical outer segment and a wider inner segment.

The newly advanced techniques, as electron microscopy and immunohistochemistry, gave more details about the photoreceptor cells. The traditional classification into rods and cones was more accurate and adequate (Cohen, 1972; Rodiek, 1973). Moreover; the cells were considered bipolar nerve cells sensitive to light. Each cell was composed of two parts; an outer photosensitive part and an inner one containing the nucleus (Aly, 2003; Altuny, 2000, 2004, 2007). In goat's, the outer and inner segments of both rods and cones were arranged parallel to each other and perpendicular to the retinal surface. This finding was in agreement with the results of Mills and Massey, (1992).

In the present investigation, as recorded in other vertebrates, rods outer segments were elongated, uniform structures and more numerous than cones outer segments. Their free ends were lodged in the apical processes of the retinal pigmented epithelium. Such microscopic findings explain the greater role of rod cells with process of vision than cone cells (CarterDawson and Lavil, 1979).

The rod outer segment of the goat's retina was formed of parallel bi membranous discs separated from each other by narrow irregular spaces. A finding met with that of Aly (2003) and Altuny, (2000, 2004). On the other hand, Braekevelt, (1990) in cat recorded regular spaces between the discs. The author mentioned that the interdisc spaceopen to the exterior that the irregularity in its rod discs was presumed to increase the surface area. The cones outer segments of goat's retina, in comparison, were short, conical in shape and their number was lesser than that of rod's outer segments (Cohen, 1972; Braekevelt, 1998; Aly, 2003).

As mentioned by many authors (Cohen, 1960; Braekevelt, 1983b; Aly, 2003), the higher content of mitochondria in cone's ellipsoid than rods explained higher metabolic activities of cones. On the other hand, Hagins, (1973) stated that the presence of a large number of mitochondria in rods than cones was mainly associated with the active sodium pump. The author added that, the mitochondrion in cones 
seems likely to have similar function, but it was not clear. Some energy production was associated with the rapid pigment turnover at high light intensities. The myoid of photoreceptors of goat's retina was found to contain numerous sER and rER. This fact was documented in other animals (Braekevelt, 1983a, 1987).

The present study revealed that the external limiting membrane of the goat's retina was formed by a series of zonulae adherents between the Müller cells and the photoreceptors. The same findings were also recorded in domestic animals (Cohen, 1972; Braekevelt, 1983a, b and 1987). The later author as well as Aly (2003) and Altuny, (2007) augmented our results that the external limiting membrane was interrupted by the cytoplasmic processes of the Müller cells.

Regarding the outer nuclear layer, there were a quite agreement among the histologists that such layer contained many rows of nuclei of rods and cones (Samuelson, 1999; Derbalah, 2001; Aly, 2003). In goats, the outer nuclear layer appeared to be formed of 6-7 layers of nuclei. The most superficial layer represented the cone nuclei while the others formed the rods nuclei. These findings were in accordance with those of Braekevelt (1990); Samulson, (1999); Ehrenhofer, (2002). There were a great resemblance between goats and other vertebrates in the electron microscopic picture. Whereas, the cone nuclei were large in size and euchromatic, the rod nuclei were smaller in size and heterochromatin (Shively et al., 1970; Derbalah, 2001; Aly, 2003). According to the fact that the more euchromatic nuclei, the increased activity of the cells, the cone cells was believed to be the more active than the rod cells. This conclusion supports our results of the presence of more numerous mitochondria in cone inner segments than those in rods.

The present investigation revealed that the outer plexiform layer was formed of axon terminals of rods and cones. These results pass in line with that of Cohen, (1972), Dellman and Collier, (1987); Samuelson, (1999). As stated by Derbalah, (2001), the cone pedicles were larger than the rod spherule. The outer plexiform layer of canine retina (Shively et al., 1973) resembled that of goat's retina as it showed synapse between axons of photoreceptors, horizontal cells and bipolar cells.

The appearance of a double - walled blood vessels in the outer plexiform layer of bovine (Aly, 2003) was also met in the goat's retina. It increased protection of the retina from rupture and also to support the blood retinal barrier.

The occurrence of four cell types in the inner nuclear layer of retinae of most animal species; horizontal, bipolar, Müller and amacrine cells (Ehrenhofer et al., 2002; Aly, 2003) could be easily distinguished in goat's retina.

The goat's horizontal cells were large oval cells contained spherical to oval nuclei and electron - lucent cytoplasm. The dendrites of such cells run horizontally parallel to the retinal surface. These results were in accordance with those of Nilson et al., (1973a); Samuelson, (1999); Derbalah, (2001). The latter author found that horizontal cells synapsed with the photoreceptor cells and bipolar cell processes. The occurrence of two types of horizontal cells as recorded by Klab et al., (1992) could not be noticed in the goats.

In goat's retina two types of bipolar cells were recorded; those with euchromatic and those with heterohromatic cells. Stell, (1967); Nilson et al., (1970); Derbalah, (2001) supported our results. The role of bipolar cells as interreceptor contact between the photoreceptor and the ganglionic cells was a constant function of bipolar cells in the opinion of most histophysiologists.

The Müller cells in the present investigation appeared as elongated or angular cells with many cytoplasmic processes that extended between the external and internal limiting membranes. The same description was reported in most vertebrates by Samuelson, (1999); Derbalah, (2001); Ehrenhofer et al., (2002). The authors agreed that Müller cells were mainly supportive in function. Uga and Smelser, (1973); Nishizono et al., (1993) added that the vitreal part of the Müller cells processes end feet which had the ability to phagocytose any foreign substances reached the area.

As stated by many authors, the amacrine cells could be easily identified in the goat's retina by their deeply invaginated nuclei (Nilson et al., 1973a; Samuelson, 1999). Their cell bodies were present in the innermost zone of the inner nuclear layer. On the contrary, Ehrenhofer et al., (2002) mentioned that the amacrine cells formed rows of cells closest to the sclera and they were identified by their exceptionally wide cytoplasmic rim. There was a quite agreement that the amacrine cells played an important role in the interreceptor connection in the retina. The inner nuclear layer contained double - walled capillaries. They considered a direct continuation 
in the outer plexiform layer and have the same importance.

Our study revealed that the inner plexiform layer was formed mainly of the cytoplasmic processes of bipolar, amacrine and ganglionic cells. Dowling and Boycott, (1967) could identify synaptic ribbon containing processes in the human inner plexiform layer as a bipolar terminals. The same author described the most typical synapse as a dyad where the bipolar terminal formed a presynptic condition with two processes, one being a ganglionic cell process and the other was amacrine cell process. In this respect, the present study could differentiate between the process of bipolar cells that contain vesicles and ganglionic cell process which was free from them. This was, also, stated by Nilson et al., (1973a); Samuelson, (1999); Aly, (2003).

The ganglionic cell layer in the present investigation resemble that described by Harman et al., (2001); Derbalah, (2001); Ehrenhofer et al., (2002) as it contains two types of cells arranged in one row; one large spherical cells having a large vesicular nucleus with prominent nucleolus and abundant organelles and smaller ganglionic cells with smaller nuclei. On the other hand, Boycott and Wassals, (1974) described three types of ganglionic cells; $\alpha, \beta$ and $\gamma$. The smaller cells in the ganglionic layer of goat's retina have a great morphological resemblance to Müller cells a finding which was recorded, also, by Ehrenhofer et al., (2002) in equine.

There was a general agreement that, in all animal species, the retinal nerve fiber layer represented the axons of ganglionic cells which coalesced to form the optic nerve. In goats, our study revealed that the intraocular nerve fibers, which represented the scleral, the chroidal and the retinal parts, were totally unmyelinated as it was in canine (Shively et al., 1970); camels (Derbalah, 2001) and bovine (Aly, 2003). On the contrary, Miyake et al., (2004) in dogs reported that the scleral and the chroidal sections consisted largely of myelinated fibers. The failure of myelination in the intraocular fibers seemed to be due to prevention of oligodendrocytes progenitor cells (oligodendroblasts) to migrate from the extraocular into the intraocular sites (Frenchconstant, 1988; Perry and Lund, 1990). Miyake et al., (2004) Supposed that the less myelination of the axons of the retinal nerve fiber layer was due to the more transparency of the retina. In sub - mammals, the retina contains oligodendrocyte and myelinated fibers but was not opaque.
The retinal nerve fiber layer runs parallel to the long axis of the retina and was supported by supportive glia cells mainly Müller cells, these results came in accordance with (Dellman and Collier, 1987; Samuelson, 1999).

\section{References}

Altuny, H. (1997): keçilerde retina pigment epiteli, Bruch's membrani ve koriokapilris' in ince yapisi. Ankara Univ. Vet. Fak. Derg., 44:183-191.

Altuny, H. (2000): Fine structure of the retinal pigment epithelium, Bruch's membrane and choriocapillaries in the horse. Anat. Histol. Embryol., 29:135-139.

Altuny, H. (2004): Fine structure of the retinal epithelium, Bruch's membrane and choriocapillaries in the Ostrich. Anat. Histol. Embryol., 33: 38-41.

Altuny, H. (2007): Fine structure of the retinal pigment epithelium, Bruch's membrane and choriocapillaries in the camel. Anat. Histol. Embryol., 36(2):116-120.

Aly, K. (2003): Glycohistochemical, immunohistochemical and electron microscopic examination of the bovine eyeball.Ph.D., Fac. Vet. Med. Ludwig- MaximiliansMunich Univ.

Bancroft, J. and Stevens, A. (1996): Theory and Practice of Histological techniques. $4^{\text {th }}$ Ed., Churchill- Livingstone, Edinburgh, London, Melbourne, New York.

Banks, W. J. (1993): Applied Veterinary Histology. $3^{\text {rd }}$ Ed. Mosbyyear book. St. Louis, Baltimore, Boston, Chicago, London, Philadilphia, Sydney \& Toronto PP. 481-484.

Bok, D. (1985): Retinal photoreceptor - pigment epithelium interactions.Invest. Ophthalmol. Vis. Sci., 26: 1659- 1694

Boulton, M. (1991): Ageing of the retinal pigment epithelium. In: progress in the retinal research, II $(\mathrm{N}$. N. Osbsrnea and G. J. chader, eds). Oxford; Pergamon press. PP. 125 - 151.

Boulton, M. and Dayhaw -Barker, B. (2001): The role of the retinal pigment epithelium: Topographical variation and ageing changes. Eye 15:384-389.

Boycott, B. B. and Wassle, H. (1974): The morphological types of ganglionic cells in the domestic cat's retina. Am. J. Physiol. 226: 397-400.

Braekevelt, C.R. (1982): Fine structure of the retinal epithelium, Bruch's membrane (Complexus basalis) and choriocapillaries in domestic ferret. Acta. Anat., 113: 117127.

Braekevelt, C.R. (1983a): Fine structure of choriocapillaries, bruch's membrane and retinal epithelium in the sheep. Anat. Embryol. 166: 415-425.

Braekevelt, C.R. (1983b): Retinal photoreceptor fine structure in the domestic sheep. Acta Anat. (Basel). 116(3): 665- 675.

Braekevelt, C.R. (1987): photoreceptor fine structure in the vervet monkey (Cercopithecus aethiopos). Histol. Histopath. 2(4): 433-439.

Braekevelt, C.R. (1988): Retinal epithelial fine structure in the vervet monkey (Cercopithecus aethiopos). Histol. Histopath. 3 (1): 33-38.

Braekevelt, C.R. (1990): Fine structure of the retinal photoreceptors of the domestic cat (Felis catus). Anat. Histol. Embryol. 19: 67 -76.

Braekevelt, C.R. (1998): Fine structure of the retinal photoreceptors of the emu ( Dromius novehollandie). Tissue and Cell. 30(2): 137-148.

Carter - Dawson, L. D. and Lavil, M. M. ( 1979):Rods and cones in the mouse retina. I. Structural analysis using 
light and electron microscope. J. Comp. Neurol. 88(2): 245 -262 .

Cohen, A. I. (1960): The ultra structure of the rods of the mouse retina. Am. J. Anat., 107: 32-42.

Cohen, A. I. (1972): Rods and cones .In: "Hand book of sensory Physiology". Vol. VII/1: photochemistry of vision. Editor: Dartnall, H. J. A. Springer - Verlag, Berlin 245 263.

Dellman, H. E. and Collier, L. L. (1987): Eye. In: "Textbook of Veterinary Histology". $3^{\text {rd }}$ ed. Lea \& Febiger. Philadilphia pp. 423- 456.

Derbalah, A. E. M. (2001): Light \& Electron microscopical studies on the eye of one - humped camel (Camelus dromedaries). M. V. Sc. Thesis. Alex. Univ., Fac. Vet. Med., Cytol. \& Histol. Dept. Acta Soc. Ophthalmol., 84: 1376-1384.

Dowling, J.E. and Boycott, B.B. (1967): Proc. Royal Soc. Ser. B. 166: 80. (Cited by Nilsson et al. 1973a).

Duke - Elder, S. S. (1958): System of Opthalmology. Vol. I. The Eye in evolution. Henry Kimpton. London.

Ehrenhofer, M. C. A.; Deeg, C. A.; Resse, S.; Liebich, H. G.; Stangassinger, M. and Kaspers, B. (2002): Fine structure and age related changes of the equine retina. Veterinary Ophthalmol., 5(1): $39-47$.

Enoch, J. M. (1979): Vertebrate receptor optics and orientation. Doc. Opthlalmol., 48: 373 - 388.

French- constant, C.; Miller, R.H.; Burne, J. F. and Raff, M. C. (1988): Evidence that migratory oligodendrocyte-type-2 astrocyte (O-2A) projenitor cells are kept out of rat by a barrier at the eye-end of the optic nerve. J. Neurocytol. 17:13-25.

Hagins, W. A. (1973): The visual process. The Annual Review of Biophysics and Bioengineering. 1: 131-158.

Harman, A., Dann, J., Ahmat, A., Macauda, T., Johnston, K. and Timney, B. (2001): The retinal ganglionic cell layer and visual acuity of the camel. Brain Beh. Evol., 58: 15-27.

Hees, H. and Sinowatz, F. (2000): Sinnesorgane- Auge (Oculus).In: "Histologie Kurzehrbuch der Zytologie und Mikroskopishen Anatomie" .3. Überabeitete Auflage. Destscher arzte - Verlag Köln, 384,400.

Kassab, A. and Sugita, S. (2001): Study of distribution of retinal blood vessels in buffaloes. J. Vet. Med. Sci., 63 (8): 917-920.

Klob, H.; Linberg, K. A. and Fisher, S. K. (1992): Neurons of the human retina. A Golgi study. J. Comp. Neurol., 318: 147- 187.

Kuwabara, T. (1979): Species difference in the retinal pigment epithelium. In: "The Retinal pigment epithelium". (eds K. M. Zinn and M. F. Marmor) Havard University Press, Cambridge, Massachusetts, $58-82$.

Mills, S. L. and Massey, S. C. (1992): Morphology of bipolar cells labeled by DAPI in the rabbit retina. J. Comp. Neurol., 321: 133-149.

Miyake, E.; Imagawa, T . and Uehara, M. (2004): Fine structure of the retino- optic nerve junction in dogs. J. Vet. Med. Sci., 66(12): 1549 - 1554.

Mohamed, S. A. (2004): Some anatomical studies on the eye of Ostrich. A Thesis of Master Degree, Suez Canal University, Faculty of veterinary Medicine, Anatomy and Embryology Department.

Nilsson, S. E. G. (1978): Ultra structure organization of the retinal pigmented epithelium of the cynomologus monkey. Acta Ophthalmol. 56: 883 - 901.

Nilsson, S. E. G.; Knave, B. G.; Lunt, T. and Persson, H.E. (1973a): The morphology of the sheep retina. I: The receptor cell and the pigment epithelium. Acta Opthalmol. 51: $599-611$.

Nilsson, S. E. G., Knave, B. G., Lunt, T. and Persson, H.E. (1973b): The morphology of the sheep retina. II: The inner nuclear layer, the ganglionic cells and the plexiform layers. Acta Opthalmol. 51: 612 - 627.

Nishizono, H., Murata, Y., tanaka,, M., Soji, D.C. and Herbert, D. C. (1993): Evidence that Müller cells can phagocytize e.g Lecithin- coated silicon particles.Tissue and cell 25: $305-310$.

Perry, V.H. and Lund, R.D. (1990): Evidence that the lamina cribrosa prevents intraretinal myelination of retinal ganglion cell axons.J. Neurocytol. 19: 265- 272.

Polyak, S. L. (1957): The vertebrate visual system. Univ. Chicago Press: Chicago.

Reynolds, E.S. (1963): The use of lead citrate at high $\mathrm{pH}$ as an electron opaque stain in electron microscopy. J. Cell Biol. 17:208-212

Richardson, K.C; Jarett, L. and Finak, E.M. (1960):Embedding in epoxy resins for ultra thin sectioning in electron microscopy.Stain Technol. 35: 313-323.

Rodiek, R.W. (1973): The vertebrate retina. Principles and function. freeman, San Fransisco.

Samuelson, D. A. (1999): Ophthalmic Anatomy. $3^{\text {rd }} \mathrm{Ed}$. In "Veterinary Ophthalmology". Editor: Gellatt Lippincott, Williams and Wilknis. A wolters Kluwer Company.Philadilphia. Paltimore. New York. London. Buenos Aires. Hong Kong. Sedney. Tokyo.

Samuelson, D. A. (2007): A textbook of Veterinary Histology. Copyright (C) 2007 by Saunders, an imprint of Elsevier Inc.

Schultze, M. (1866): Anatomie und physiologie der netzhaut. Arch. Mikros. Anat. Entw. Mech. 2: 175-286.

Shively, J. N.; Epling, G. P. and Jenesen, R. (1970): Fine structure of the canine eye: Retina. Am. J. Vet. Res. 31: 713 $-717$.

Smell, R. K., Riddle, P. and Noble, M. (1987): Evidence for migeration of oligodendrocyte - type-2 astrocyte progenitor cells into developing rat optic nerve. Nature (Lond.) 328: 155-157.

Spira, A. W. and Milman, G.E. (1979): The structure and distribution of the cross - striated fibrils and associated membranes in guinea pig photoreceptors. Amer. J. Anat. 155: 319-118.

Stell, W.K. (1967): Am. J. Anat. 120. 401. (Cited by Nilsson et al. 1973).

Uga, S. and Smelser, G. K. (1973): Comparative structure of the fine structure of the retinal Müllercells in various vertebrates. Invest. Ophthalmol. 12: $434-448$. 


\section{دراسة بالمجهر الضوئي و الاككتروني على شبكية العين في الماعز}

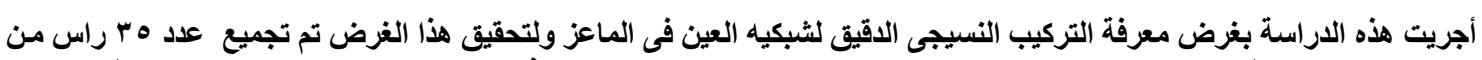

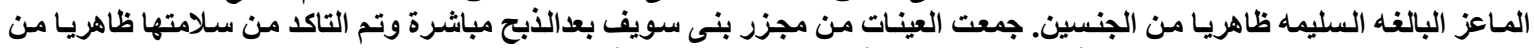

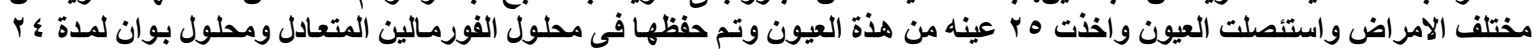

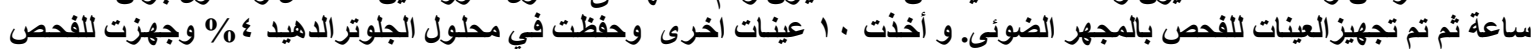

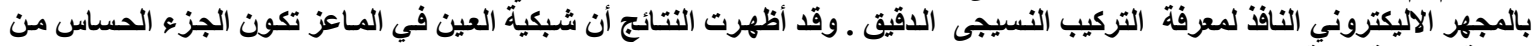

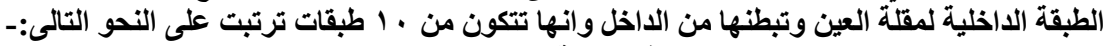

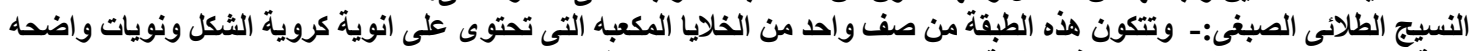

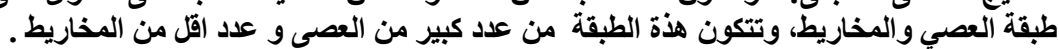

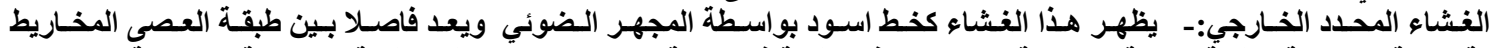

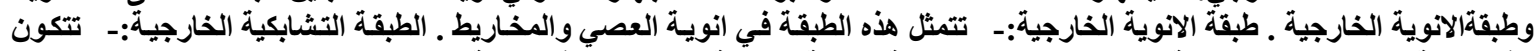

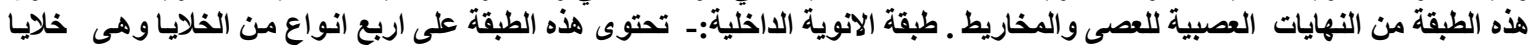

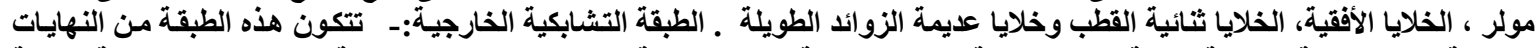

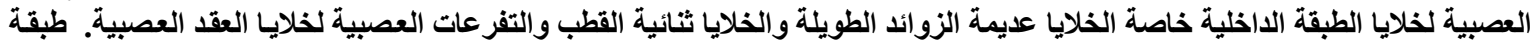

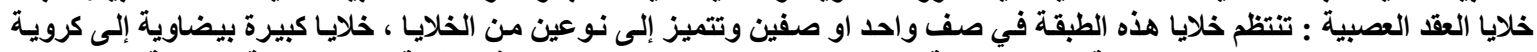

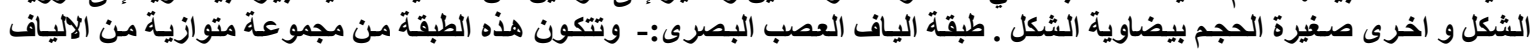

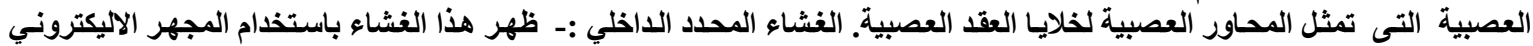

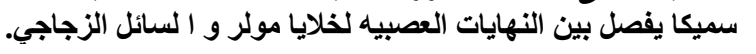

